\title{
See-sawing between work and home: Shift-working mothers' perceptions on work/family balance
}

Huhtala, Eija

University of Lapland, Finland (eija.huhtala@elisanet.fi)

Uusiautti, Satu $\bowtie$

University of Lapland, Finland (satu@ uusiautti.fi)

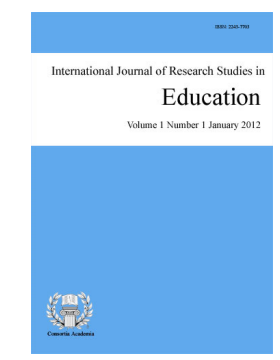

Määttä, Kaarina

University of Lapland, Finland (kaarina.maatta@ulapland.fi)

ISSN: 2243-7703 Online ISSN: 2243-7711

OPEN ACCESS

\section{Abstract}

Recent public discourse and studies are filled with issues related to work/family balance. Shift work concretely affects family life considerably already starting from the schedule the family has to follow because of one or both parents' work shifts. The purpose of this study is to contribute by dissecting shift worker-mothers' perceptions on the balance between shift work and family life. This research was a qualitative study where eight shift-working mothers were interviewed. This phenomenon is studied through the following research questions: 1.) what kinds of experiences shift-working mothers have on motherhood; 2.) What kinds of experiences shift-working mothers have on their work; and 3.) What factors do they bring out concerning the family/work balance? As a conclusion, a typology that illustrates shift working mothers' perceptions on the success of work/family balance in their life will be introduced.

Keywords: shift work; motherhood; work/family balance; families with children; working life 


\section{See-sawing between work and home: Shift-working mothers' perceptions on work/family balance}

\section{Introduction}

Shift work concerns a number of families and is a widely studied phenomenon as people in various occupations all the way from nurses (Camerino et al., 2010) to industrial workers (Ljoså \& Lau, 2009), military workers (Hertz \& Carlton, 1989), and for example, in retail stores (Chuang \& Lei, 2011) work in shifts in nonstandard hours - just to name few. Shift work concretely affects family life considerably already starting from the schedule the family has to follow because of one or both parents' work shifts. If lack of time is usual in families with children overall, the same concerns certainly families with children and shift-working parent(s). Parents' work and modern busy life-style take time and often family-time is spent during short moments in the evenings and weekends. Especially in families with small children, experiences of busyness are common. When one or both parents are shift workers, they have joint days off and free weekends even more infrequently. Although shift work may hinder family life, many find also positive sides in it.

The combination of work and family life has been studied increasingly since women started to work outside home (Barnett, 2004; see also Aryee, Srinivas, \& Hoon Tan, 2005). At the same time, men started to use more and more time with housework and childcare during the past few decades (Barnett, 2004). In Finland, the possibility to combine work and family has been supported also with social policy (Salmi, 2004); and financial matters, indeed, are of great importance in this phenomenon (see e.g. Barnett, 2004; Barnett \& Lundgren, 1998). Indeed, Finnish women have worked outside home historically longer than in many other western industrial countries (Kinnunen, 1997). In Europe, Nordic Countries are considered pioneers in questions of the combination of work and family (Hämäläinen \& Kangas, 2010). In many Central European countries, such as in France, Germany, and Holland, most women work part-time (Kinnunen, 1997). In Finland, both parents of the vast majority of families with children under school age are in full-time employment (MSAH, 2006). The female labor force participation in Finland is $72 \%$ of women (15-64 years), only $18.2 \%$ of whom are in part-time employment. Furthermore, the labor force participation rate of women with a child or children under 6 years is $49.6 \%$ of whom $8 \%$ work part-time (OECD, 2006). About a quarter of Finnish workers have shift work (Partinen, 2010).

Recent public discourse and studies are filled with issues related to work/family balance. Yet, only little changes have taken place in families' daily life. Although individual people may appreciate family greatly but it may not always be the number one in the society's values. Fast changes in modern family structures and working life call for research: the purpose of this study is to contribute by dissecting shift worker-mothers' perceptions on the balance between shift work and family life. Furthermore, the purpose of this article is to contribute to research that focus on personal experiences by giving space for the voices of the research subjects as there is need for the individual case studies that examine ways that individuals cope with specific life events or challenges (see Perrone, Wright, \& Jackson, 2009).

\section{On Modern Parenthood and Work/Family Balance}

Family life — together with working life — has been under dramatic change during the past few decades. People talk about the crisis, erosion, and even dissipation of family. Starting a family is still, however, popular and having a family is considered as one of the most important things in people's life (Huttunen, 2000.) The decisions that a couple has to make relating to their careers are fundamentally based on the economic and social factors as well as on the attitudes on working. Additionally, the situation at the work place and individual factors are significant. A couple has to reflect the biological, psychological, and economic needs of both spouses. They may end up with an arrangement where 1.) Both work full time and standard work schedules; 2.) Both work 
full-time, non-standard work schedules; 3.) One works full-time, one works reduced hours; or 4.) Both work reduced hours (Barnett \& Lundgren, 1998).

Family/work balance can also be dissected from the point of view of social roles. Frone (2003) refers to the family-work balance in this matter. The imbalance between the social roles may produce stress that further has an effect on different areas of life and the individual's health and well-being. Most of the studies have focused on the work/family - conflict, but Frone (2003), for one, defines the work/family balance as lack of conflict or interference between the work and family roles.

According to Clark's (2000) theory about work and family balance people are daily border-crossers between the domains of work and family. The theory addresses how domain integration and segmentation, border creation and management, border-crosser participation, and relationships between border-crossers and others at work and home influence work/family balance. Such concepts as permeability, flexibility, and blending are used to describe the border between work and family. Permeability refers to the degree to which elements from other domains may enter. Flexibility is the extent to which a border may contract or expand depending on the demands of one domain or the other. When a great deal of permeability and flexibility occurs around the border, blending both work and family it creates a borderland which cannot be called either domain (Clark, 2000.)

In this research, our focus is on shift work. There are studies on shift work and its influence on family life, and especially the negative spillover (Camerino et al., 2010; Grosswald, 2003), and the use of coping strategies (Ljoså \& Lau, 2009). In Finland, for example, Härmä, Sallinen, and Kandolin (2000) introduce problems that shift work causes to family life. According to the researchers (2000), problems are mostly connected to social issues: a shift worker may find it often difficult to adjust his or her work and leisure periods to the prevailing rhythm of life in the rest of the society. Thus, it is more difficult to spend time together with the family and friends and have hobbies. Certainly, there is a relationship between whether parents work shifts and their time spent with children, although that relationship is somewhat complex. For example, Presser (2003) found that parents working certain nonstandard shifts were less likely to eat dinner with their children; the effect depended in part on which shift parents worked. Meanwhile, some nonstandard shifts had a positive correlation with whether parents had breakfast with their children.

However, also shift work may offer different opportunities to alter shifts and work schedules (see Beers, 2000, p. 37; see also Lammi-Taskula \& Salmi, 2004) and there are positive sides in shift work as well. Shift work may be appreciated because it offers more jobs and increase income. Days off in weekdays are one of the positive sides. In many work places, shifts are determined in longer periods and free time may be arranged in a flexible manner (Helasti, 2002). Yet, families with children tend to perceive shift work more negatively than childless children. And, according to a Finnish Well-being Survey (2005) the younger the children are, the worse shift work suits the life situation (see Hyvinvointikatsaus, 3/2005). It is understandable because shift work limits family time during evening, weekends, and Holidays, which are often considered important in families with children. In addition, day-care centers' opening hours are not usually suitable for shift workers (Härmä, Sallinen, \& Kandolin, 2000).

\section{Methodology}

\subsection{Research Questions}

The purpose of this research was to describe and understand shift-working mothers' perceptions on the work/family balance. This phenomenon is studied through the following research questions:

1. What kinds of experiences shift-working mothers have on motherhood?

2. What kinds of experiences shift-working mothers have on their work? 
Huhtala, E., Uusiautti, S., \& Maatta, K.

3. What factors do they bring out concerning the family/work balance?

As a conclusion, we will introduce a typology that illustrates shift working mothers' perceptions on the success of work/family balance in their life.

\subsection{Data Collection and Analysis}

This research was a qualitative research with a phenomenographic approach. It is a suitable method for studying people's perceptions on daily phenomena (Huusko \& Paloniemi, 2006). The phenomenographic approach has emphasis on the contextual nature of a phenomenon. According to Rissanen (2006), a researcher has to aim at bringing out the context to which the interviewees' perceptions are connected. The basic assumption is that people's experiences are always connected to the situation and context where they happen (Marton, 1994; Marton \& Booth, 1997). In phenomenographic research, data is usually collected through qualitative interview. In this study, data collection method was theme interview: interviews focused on certain, pre-determined themes. In addition, theme interview allows changing the sequence of questions and thus interviewees' interpretations and experiences become central (Tuomi \& Sarajärvi, 2009).

When recruiting participants in this research, it was considered important that the interviewees would have children and several years' long experience on shift work. There were not any other specific criteria for selecting participants. Altogether eight persons were interviewed in October 2011. The participants had approximately two children. One of them had four children and she was also a single mother. The participants had either two-shift or three-shift work in caring or trade industries. Their work experience varied between five and fifteen years of shift work. Interviews were carried out at the participants' homes or work places and lasted for hour - hour and a half. Focusing on shift-working mothers made it possible to study the theme through such participants' perceptions who had children and years' long experience on shift work (see also Darbyshire, 1994). When it comes to the data analysis, an entity is constructed from the singular cases in order to reveal the overall nature of the phenomenon studied (Huusko \& Paloniemi, 2006). Data analyzing method was, therefore, qualitative categorization.

\subsection{Reliability of the Research}

The aim of qualitative research is to provide a meaningful interpretation of the phenomenon. Therefore, the quality of data is more relevant than the number of participants (Eskola \& Suoranta, 1998). Naturally, some criticism can be directed to the represententativeness of the participants as they were discretionarily selected. However, the interviews succeeded well and the data gathered was abundant. For example, according to Saarnivaara (1996), it is crucial for the reliability and ethicality of research that an interviewee can bring out his or her experiences and opinions as freely as possible. Although the results as such as not generalizable, they do elicit mothers' experiences on work/family balance. To increase the reliability of interpretations, excerpts from the data are added within the results section.

\section{Results}

\subsection{Shift-working Mothers' Perceptions on Motherhood and Family-life}

Firstly, mothers in this research discussed their motherhood. For them, motherhood appeared as a natural part of life. Only one of them had not planned of becoming a mother while most of them had dreamt of a family. Family was perceived as a source of support and security. However, becoming a mother represented a change in life that turned children and the family the most important thing in life. For some of the participants the primacy of family had been axiomatic at once after having children while others had realized that through everyday experiences. Many of the participants emphasized the significance of being together and spending time together, and the peaceful everyday life. 
See-sawing between work and home: Shift-working mothers' perceptions on work/family balance

"If I did not have my family, I would not be this kind of person; and all difficult issues tend to follow me at home, so my family supports me."

"A year ago, I started to notice that my family suffers as I had too much all sorts of positions of trust and such. Even my children started to complain that mother is always going somewhere. Since that I have been cutting off my goings [--] I have cut off all that kind of extra activity. And otherwise we have deliberately tried to do so that we don't go somewhere every night."

Motherhood also affects one's values. Mothers who were interviewed in this research told how they now can empathize those workers who have small children. Many of the mothers told that they could make their working more efficient to have more free time. However, it is not usually possible in shift work.

When contemplating the traditional definition of good motherhood - consisting of a regular rhythm of life, care, and presence - mothers in this research did not think that shift work would significantly bother these aspects of motherhood. However, quite many of them felt like being single mothers as the parents were not very often at home at the same time. Still, either one of them was at home almost always which was, nevertheless, considered important.

In this research, most participants reported having quite a traditional distribution in housework: they had men's and women's work. Yet, what was the best for the children was considered the most important: mothers highlighted that the home does not have to be perfect. Because of their shift work, many mothers thought that their spouses do more housework and drive children, for example, to their hobbies than what they would do if the mother had a regular 9-to-5 job. Shared parenthood, where men did their share of housework, functioned well in these families. Still, mothers' seemed to have the main responsibility for taking care of housework. This result is line with, for example, Piensoho's (2006) and Uusiautti's (2008) research: both parents' participation in housework help keeping the balance between work, home, and children. Piensoho (2006) mentioned that already parents' presence and availability are significant as such and time spent with children is usually perceived as important.

Most mothers in this research told that they were very family-centered. At the same time, they brought out the thought that this attitude is also a challenge because of today's pressures. On the other hand, the family was considered a good counterbalance to work. Eventually, the family was the number one in their scale of values.

"The family gives you so much. At times, it is like, as the children are not that young anymore, that you have to discuss and contemplate things. On the other hand, it's extremely rewarding. If I didn't have my family - I cannot even really imagine that. Children bring so much content to your life although you have to take care of them."

"Well, the family certainly is a challenge but it is also a resource. Without my family, I couldn't cope. I have some challenges for example at work, it keeps the balance."

Some of the mothers waited anxiously for their small children to get little older. In addition, children require so much attention that it cuts off the time spent together. Some shift-working mothers described also their feelings of guilt because they had a shift work compared to the situation if they had a regular day-time job. They told that they tried to compensate this by, for example, taking children with them always when going out or traveling.

Mothers in this research also expressed their desire for having more time with their family. Yet, surprisingly many thought that they had enough time or at least sufficiently considering their present life situation. On the other hand, many of them recognized the importance of social networks and none of them dreamed of being a housewife. Although the family was named as number one priority, conflict situations and busy periods at work may occasionally make them do their work first. In addition, some of them told that they do not have time to think about their family issues at work nor answer the phone. 
Huhtala, E., Uusiautti, S., \& Maatta, K.

Time spent with the family gave strength at work. Most of the mothers told they lived quite ordinary life doing housework and yard work, exercising outdoors, and going for little shopping trips neighborhood markets. Small, everyday doings seemed to be the ones they enjoyed the most. In two families, children's hobbies were relatively time-consuming but otherwise families tended to spend their free time at home.

"We have quite usual everyday life. I am somewhat a home person and a sort of well-functioning everyday life is the best for the children and that's enough for them. Of course, I could devote more to my marriage."

Overall, it seemed that the shift-working mothers were quite content with the time they spend with their children. Still, many of them would like to have more time for just be with the children, for example to play with them.

\subsection{Shift-working Mothers' Perceptions on Work}

Most of all work represented a social network to mothers in this research. They appreciated their co-workers and the opportunity of belonging to some community. Co-workers also motivated them to cope at work and some co-workers had even become good friends. The family is also visible in the work community already because of the nonstandard working hours. They had, for example, noted that the work community becomes better-knit because they have to work also on Holidays. It strengthens the sense of solidarity.

"You enter the work community as a family; basically, you are more than just another worker there."

According to the interviews, shift work brings change in weekdays. In addition, many of them thought that those who have a shift work must really prefer it-otherwise, you could not do it. Naturally, many of the participants worked in health care and social services and therefore, they might naturally find they work important as their work consists of helping and caring for other people. Nearly everyone told that they found their work a vocation.

"I really do like this work with the elderly. They can be so grateful and it is a part of my natureto desire to help others."

"It is the thing that you belong to somewhere. Success at work feels important; I am needed for something, especially in nursing."

The interviewees told that work also represented a possibility to independency and self-fulfillment. They wanted to put in use the skills and knowledge gathered in education. Therefore, they did not work just for the financial remuneration but merely worked for quality outcomes (see also Ryan \& Deci, 2000a, 2000b).

However, some concerns were expressed as well. Many of the interviewees reported that they were little uncertain of the stability of their work. Indeed, working life has changed during the past few years and competition, conflicts, and demands have increased. Everyone in this research wanted to have a permanent job and this wish was everyone's dream. Most of them had one at the moment of data collection but surprisingly many of them had some doubt of the permanence.

"Along with having a private owner, our certainty has not increased in any way... We have been talking with co-workers that there is a little fear that our work ends someday."

Although the fear of losing a job is even more drastic in families with children, the participants in this research were not overly worried. Instead, they saw their future as a field of many opportunities.

\subsection{Shift-working Mothers' Perceptions on the Work/Family Balance}


Although all participants considered their family more important than their work, many had to admit the fact that work follows them at home. Only two of the mothers told that they were able to clearly distinguish work and family life. The first of them worked in a different area and had plenty of housework since her spouse was an entrepreneur. Therefore, she tried to deliberately concentrate just on her family during leisure. Likewise, the mothers described how they pursued leaving their work-related matters at work but after a busy work day, they may not have the energy to anything at home as it takes time to recover for the next work day.

"Of course, it affects your social life more. You don't see your friends very often and you are not able to participate in your children's hobbies all the time. So they suffer and you have to delegate who picks up the children. You remember much more by using check lists."

Work and family roles seemed to be somewhat overlapping. At their best, they both can function as sources of joy and strength and thus support each other. People who experience joy of working and work drive are likely to keep up with that mood at home as well (see e.g. Uusiautti \& Määttä, 2010ab; 2011ab).

Shift work was not the best option in every life situation. However, all mothers in this research named plenty of good sides that shift work has. Especially, days off during weekdays were appreciated. When children are small, shift work was considered good if one was able to arrange child care flexible with the spouse. Furthermore, one of the parents is at home always when children leave or come home. Yet, the danger was that spouses may not necessarily see each other often as they do not work at the same time. All of the mothers told that they had a planner that they used with their spouse to plan and arrange the everyday life relatively smoothly.

"At the moment, shift work is good because you have days off during weekdays. I present during the weekdays and some of my children make it home before I go to an evening shift. I would be less present if I had a 9-to-5 work."

"Sometimes I have contemplated that when my children grow older a 9-to-5 job could be better. Now I have, however, enough time for my children."

"I somehow think that those are important situations when the children come back from school. We have a good situation because my husband has a 9-to5 job and it does require of him a lot to be more at home and cook and so on."

Many shift-working mothers in this research told that they relaxed by doing ordinary things, exercising outdoors and such. None of them had any particular hobby partly because of nonstandard working schedule but also because they did not have the energy for a hobby.

"I don't have any regular hobby but I haven't thought that I wouldn't have my own time. Mornings before going to an evening shift or a day off are my time-whether I do housework or go to stores."

The interviewees named plenty of good things in their work and everyday life. It seemed that happiness at work and in family life consists of small things and choices. The combination of shift work and family is totally possible and many people succeed well. If work shifts remain fair in their length, it reflects positively in family life as well.

According to the interviewees, it is important to pay attention to an individual employee's hopes and wishes whenever possible. When work shifts are settled long in the future, it is easier to make plans with the family as well. Balance between free weekends and evening shifts increase happiness especially in families with small or school age children.

The mothers in this research appreciated the support and concrete help they got from the family. Indeed, they also thought that shift-workers' children may become more likely self-directed and helpful children. In 
Huhtala, E., Uusiautti, S., \& Maatta, K.

many families in this research, children had tasks appropriate to their age that they had to take care of and thus had responsibility of some housework, too.

\section{Discussions}

Based on the abundant interview data and results, we created a typology to illustrate the balance between shift work and family. The combination of work and family is challenging but there were certain variations on how the balance could succeed.

Three shift work/family balance types could be found based on this research:

1. First, there were those who have succeeded in finding a balance between shift work and family. These mothers enjoyed both their work and their family life and had figured out how to combine these two areas of life successfully regardless of their conflicting schedules and other issues. Frone (2003) refers to lack of conflict but this type can be more than that: work/family balance may also have a positive affects — not just lack of interference.

2. The second type represents those shift-working mothers who see-saw between the family and work. They have not found a balance and one area bothers another. These mothers may, for example, enjoy their work but may find family-related duties and housework strenuous or overwhelming. Or vice versa: they may enjoy their family life and would like to devote to it more but their work seems to hinder it of work tend to follow them at home.

3. The third type consists of those shift-working mothers who have not found the balance between work and family and, in addition, both areas of life appear as burdening.

When assessing these three types, it would be worth considering whether there is a way to turn these areas of life rewarding and supporting. In some theories, the contrariness of the experiences in these areas of life can be emphasized (Kinnunen et al., 1995) — this is the case, for example, among type two shift-working mothers. This compensation theory suggests that an individual tries to compensate for an insufficiency in one area of life if the other, for example, work or marriage, fails to satisfy him or her (Lambert, 1990).

When considered from a positive point of view, type two mothers may learn to draw strength from the other area of life and thus start to have success in the more demanding one as well. Studies focusing on the expanding and positive outcomes of multiple roles (e.g., the roles of an employee, a spouse, and a parent) embody the positive perspective (Kinnunen et al., 1995). Multiple roles - or in other words the role accumulation that means managing a variety of roles at the same time_-enhance an individual's self-respect (Marks \& MacDermid, 1996), diversify one's personality, and improve one's social skills (Gutek et al., 1988). In addition, role accumulation prevents depression and increases personal latitude, quality of life, and perceived well-being (Marks \& MacDermid, 1996).

\section{Conclusions}

The study showed how the combination of work and family is quite a multi-faceted phenomenon. Parents have to balance between various areas of life. Yet, there are many ways of combining work and family through which well-being, development, and contentment in various areas of life increase. Work and family do not exclude each other: one can be committed to these both at the same time - even if the work was a shift work.

Grosswald's (2003) study found out that there is a strong, significant relationship between shift work and negative work/family spillover. Working non-standard, non-flexible shifts significantly increased negative work/family spillover even when controlling for education, occupation, and standard demographic variables (see also Horelli \& Wallin 2006). Root and Rudd (2001) found out in their research on American shift workers that despite lack of shared time with family members, they had learned how to coordinate their schedules as best they 
could with other family members. They also appreciated the help other relatives and friends offered to help them manage some of their family responsibilities. Still, those who have children in child-care found it very complicated to find the services they needed - this problem was especially difficult among single parent families. Likewise, Grosswald (2003) had found out that job autonomy, a family-friendly job culture, supervisory support, and fewer work hours all significantly decrease the negative work/family spillover. When compared to the results of this research, if positively experienced family life is added to this equation, one may be able to achieve the type one situation illustrated in our typology. Not only will the negative spillover decrease but it will be replaced by the positive one: family life satisfaction, job performance, and overall well-being will increase (see also Camerino et al., 2010; Uusiautti \& Määttä, 2010).

Positive family life experiences may originate quite small things as the mothers in this research repeatedly pointed out. In addition to time spent together with children and spouse, sharing housework with especially the spouse was perceived important. However, a Swedish research (Evertson \& Nermo, 2007) implies that the compromises in sharing the housework still is not very usual: Despite women's increasing involvement in work outside home, they continue to perform the majority of household tasks and a woman's economic dependency on her spouse is related to her share of the housework - and this may also lead to decreased levels of marital satisfaction (see also Koivunen, Rothaupt, \& Wolfgram, 2009). Furthermore, it has been showed (Stevens et al., 2007) that in the dual-earner couples, for men, the relationship satisfaction was associated with positive family-to-work spillover, whereas satisfaction with the housework arrangement was related to women's positive spillover. With both men and women engaging in more nontraditional gender roles in work and family domains, there is great need to understand the impact of these roles in each domain (Perrone, Wright, \& Jackson, 2009).

When studying the connection between work and family, it is important to reflect both how the work influences the family life and also what kind of influence the family life has on work (Frone, Russell, \& Cooper, 1992; Gutek, Searle, \& Klepa, 1991), whether it is strengthening or conflicting (e.g. Aryee, Srinivas, \& Hoon Tan, 2005). The hypothesis of the strengthening effect of multiple roles (see e.g. Rantanen \& Kinnunen, 2005) is of great interest at the moment as it concerns both genders - and other family members, too. The recent studies have shown that it is not just about making compromises but, for example, that positive paternal involvement influences the multiple domains of children's lives from birth through adolescence (see e.g. Hawkins et al. 2008; Kinnunen, Malinen, \& Laitinen, 2009).

In this research, we focused on shift-working mothers' experiences and opinions. Yet, it would be interesting and necessary to study perceptions of shift-working parents' children. Not only is it important to study on the positive outcomes of work/family balance but also how parents' work affects children (Morett \& Rosenbaum, 2006). It is particularly important because of the link that has been found between even simple parent-infant interactions and children's cognitive outcomes and social and emotional development (Landry et al. 1997, Letourneau, 1997). For example Kyrönlampi-Kylmänen and Määttä (2011ab) have found out that due to a parent's paid work, the most important thing to a child — namely to spend time together with parents—does not come true during weekdays. How does shift work affect this matter or is there some difference between the perceptions of those children whose parent(s) have shift work than those who have 9-to-5 work? Being present is important for human well-being not only at work but also at home (Brown \& Ryan, 2003). Therefore, finding ways to make use of this balance is crucial in the modern working life.

\section{References:}

Aryee, S., Srinivas, E. S., \& Hoon Tan, H. (2005). Rhythms of life: antecedents and outcomes of work-family balance in employed parents. Journal of Applied Psychology, 90(1), 132-146. $<$ http://dx.doi.org/10.1037/0021-9010.90.1.132>

Barnett, R.C. (2004). Women and work: where are we, where did we come from, and where are we going? Journal of Social Issues, 60(4), 667-674. <http://dx.doi.org/10.1111/j.0022-4537.2004.00378.x >

Barnett, R. C., \& Hyde, J. S. (2001). Women, men, work, and family. An expansionist theory. American 
Huhtala, E., Uusiautti, S., \& Maatta, K.

Psychologist, 56(10), 781-796. <http://dx.doi.org/10.1037/0003-066X.56.10.781>

Barnett, R. C., \& Lundgren, L. (1998). Dual-earner couples and the decision to work less: A conceptual model. community. Work \& Family, 1(3), 273-295.

Beers, T. M. (2000). Flexible schedules and shift work: replacing the '9-to-5' workday? Monthly Labor Review, June 2000, 33-40.

Brown, K. W., \& Ryan, R. M. (2003). The benefits of being present: mindfulness and its role in psychological well-being. Journal of Personality and Social Psychology, 84(4), 822-848.

$<$ http://dx.doi.org/10.1037/0022-3514.84.4.822>

Camerino, D., Sandri, M., Sartori, S., Conway, P. M., Campanini, P., \& Costa, G. (2010). Shiftwork, work-family conflict among Italian nurses, and prevention efficacy. Chronobiology International: The Journal of Biological \& Medical Rhythm Research, 27(5), 1105-1123. $<$ http://dx.doi.org/10.3109/07420528.2010.490072>

Chuang, Y. S., \& Lei, Y. C. (2011). Retail staffs working stress and work-family conflict under shifts: Work System Study. BAI Conference Papers, 2011. Retrieved from http://bai-conference.org/BAI2011/Papers/7.OB\&HRM/7087.pdf

Clark, S. C. (2000). Work/family border theory: A new theory of work/family balance. Human Relations, 53, 747-770. <http://dx.doi.org/10.1177/0018726700536001>

Eskola, J., \& Suoranta, J. (2005). Johdatus laadulliseen tutkimukseen [Introduction to qualitative research]. Tampere: Vastapaino.

Frone, M. R. (2003). Work-family balance. In J. Campbell Quick \& L.E. Tetrick, (Eds.), Handbook of occupational health psychology (pp. 143 - 162). Washington, DC: APA. $<$ http://dx.doi.org/10.1037/10474-007>

Frone, M. R., Russell, M., \& Cooper, M. (1992). Antecedents and outcomes of work-family conflict: Testing a model of the work-family interface. Journal of Applied Psychology, 77, 65-78. $<$ http://dx.doi.org/10.1037/0021-9010.77.1.65>

Evertson, M., \& Nermo, M. (2007). Changing resources and the division of housework: A longitudinal study of Swedish couples. European Sociological Review, 23(4), 455-470. $<$ http://dx.doi.org/10.1093/esr/jem018>

Grosswald, B. (2003). Shift work and negative work-to-family spillover. Journal of Sociology and Social Welfare, Dec/2003. Retrieved from http://findarticles.com/p/articles/mi_m0CYZ/is_4_30/ai_111933182/

Gutek, B. A., Searle, S., \& Klepa, L. (1991). Rational versus gender role explanations for work-family conflict. Journal of Applied Psychology, 76, 560-568. <http://dx.doi.org/10.1037/0021-9010.76.4.560>

Hawkins, A. J., Lovejoy, K. R., Holmes, E. K., Blanchard, V. L., \& Fawcett, E. (2008). Increasing fathers' involvement in child care with a couple-focused intervention during the transition to parenthood. Family Relations, 57, 49-59. <http://dx.doi.org/10.1111/j.1741-3729.2007.00482.x>

Helasti, P. (2002). Hyvä ja paha vuorotyö [Good and bad shift work]. Hyvä Terveys [Good Health], 4/2002.

Hertz, R., \& Charlton, J. (1989). Making family under a shiftwork schedule: Air force security guards and their wives. Social Problems, 36(5), 491-507. <http://dx.doi.org/10.1525/sp.1989.36.5.03x0007g >

Horelli, L., \& Wallin, S. (2006). Arjen ajan hallintaa. Kokemuksia suomalaisesta aikasuunnittelusta [Daily time management. Experiences on Finnish time management planning]. Helsinki: The City of Helsinki Information Center.

Huttunen, J. (2000). Isästäkö äidin kaltainen vanhempi? [Would daddy become a parent similar to mother?]. In L. Laurinen (Ed.), Koti kasvattajana, elämä opettajana. Kasvatus ja oppimiskulttuurit tutkimuskohteina [Home as an educator, life as a teacher] (pp. 36-40). Juva: Atena.

Hyvinvointia vuorotyöhön [Well-being into shift work]. (2011). Helsinki: Työterveyslaitos.

Hämäläinen, U., \& Kangas, O. (2010). Perhepiirissä [Within the family]. Sastamala: Vammalan Kirjapaino Oy.

Härmä, M., Sallinen, M., \& Kandolin, I. (2000). Työajan yhteydet yksilön terveyteen, toimintakykyyn ja hyvinvointiin [The connection between working hours and individuals' health, capability, and well-being]. In M. Härmä (Ed.), Toimivat ja terveet työajat [Functional and healthy working hours] (pp. 
See-sawing between work and home: Shift-working mothers' perceptions on work/family balance

13-39). Helsinki: Työterveyslaitos, Sosiaali- ja terveysministeriö ja Työministeriö.

Kinnunen, U. (1997). Naisen työura ja persoonallisuus. Työn ja perheen vuorovaikutus [Women's career and personality. The interaction between work and family]. In L. Pulkkinen (Ed.), Lapsesta aikuiseksi [Development from childhood to adulthood] (pp. 46-58). Helsinki: WSOY.

Kinnunen, U., Loikkanen, E., \& Mauno S. (1995). Työn ja perheen vuorovaikutus: ongelmien yleisyys, syyt ja seuraukset [The interaction between work and family: the frequencies, causes and consequences of the problems]. Reports from the Family Research Unit., No. 5. Jyväskylä: The University of Jyväskylä.

Koivunen, J. M., Rothaupt, J. W., \& Wolfgram, S. M. (2009). Gender dynamics and role adjustment during the transition to parenthood: current perspectives. The Family Journal: Counseling and Therapy for Couples and Families, 17(4), 323-328. <http://dx.doi.org/10.1177/1066480709347360>

Kyrönlampi-Kylmänen, T., \& Määttä K. (2011). What do the children really think about a day-care centre - The 5 to 7 years-old Finnish children speak out. Early Child Development and Care. $<$ http://dx.doi.org/10.1080/03004430.2011.557861>

Kyrönlampi-Kylmänen, T., \& Määttä K. (2011). What is it like to be at home - The experiences of 5 to 7-year old Finnish children. Early Child Development and Care. $<$ http://dx.doi.org/10.1080/03004430.2010.540013>

Lambert, S. J. (1990). Processes linking work and family: a critical review and research agenda. Human Relations, 43, 138-143. <http://dx.doi.org/10.1177/001872679004300303>

Lammi-Taskula, J., \& Salmi, M. (2004). Aikaa työlle, aikaa perheelle [Time for work, time for the family]. In M. Salmi \& J. Lammi-Taskula (Eds.), Puhelin, mummo vai joustava työaika? Työn ja perheen yhteensovittamisen arkea [Telephone, grandmother or flexible working hours? Everyday life of work and family combination] (pp. 30-39). Helsinki: Stakes.

Ljoså, C. H., \& Lau, B. (2009). Shiftwork in the Norwegian petroleum industry: overcoming difficulties with family and social life - a cross sectional study. Journal of Occupational Medicine and Toxicology, 4(22). <http://dx.doi.org/10.1186/1745-6673-4-22>

Marks, S. R., \& MacDermid, S. (1996). Multiple roles and the self: a theory of role balance. Journal of Marriage and Family, 58, 417-432. <http://dx.doi.org/10.2307/353506>

Marton, F. (1994). Phenomenography. Göteborg: Göteborg University. Retrieved from: http://www.ped.gu.se/biorn/phgraph/civil/main/lres.appr.html

Marton, F., \& Booth, S. (1997). Learning and awareness. Mahwah, NJ: Lawrence Erlbaum Associates.

Ministry of Social Affairs and Health. (2006). Finland's family policy. Helsinki: Ministry of Social Affairs and Health. Retrieved from http://www.stm.fi/en/publications/publication/_julkaisu/1058023\#en

Morett, C., \& Rosenbaum, E. (2006). The Effect of Shift Work on Parental Interaction with Children, Marital Quality, and Depression. Extended abstract submitted for presentation at the 2007 annual meeting of the Population Association of America. Retrieved from http://paa2007.princeton.edu/download.aspx?submissionId=71820

OECD. (2006). Starting strong II: Early childhood education and care. Retrieved from http://www.oecd.org/dataoecd/16/2/37423404.pdf

Partinen, M. (2010). Epäsäännöllinen työaika ja vuorotyö [Nonstrandard working hours and shit work]. Retrieved April 21, 2010 from Terveyskirjasto [Health Library] database: http://www.terveyskirjasto.fi/terveyskirjasto/tk.koti?p_artikkeli=dlk01013\#s6

Perrone, K. M., Wright, S. L., \& Jackson, Z. V. (2009). Traditional and nontraditional gender roles and work-family interface for men and women. Journal of Career Development, 36(1), 8-24. <http://dx.doi.org/10.1177/0894845308327736>

Rantanen, J., \& Kinnunen, U. (2005). Työn ja perhe-elämän vuorovaikutus [The Interaction between Work and Family Life]. In U. Kinnunen, T. Feldt, \& S. Mauno, (Eds.), Työ leipälajina. Työhyvinvoinnin psykologiset perusteet [Work as a job. The psychological bases for well-being at work] (pp. 229-264). Keuruu: Otava.

Root, L., \& Rudd, E. C. (2001). Shift work- a work-family strategy or a deal with the devil? The Network News: A work-family news publication, 6(8). Retrieved from: 
Huhtala, E., Uusiautti, S., \& Maatta, K.

http://wfnetwork.bc.edu/The_Network_News/06/The_Network_News_Interview06.pdf

Ryan, R. M., \& Deci, E. L. (2000a). Self-determination theory and the facilitation of intrinsic motivation, social development, and well-being. American Psychologist, 55, 68-78.

$<$ http://dx.doi.org/10.1037/0003-066X.55.1.68>

Ryan, R. M., \& Deci, E. L. (2000b). When rewards compete with nature: the undermining of intrinsic motivation and self-regulation. In C. Sansone \& J. M. Harackiewicz (Eds.), Intrinsic and extrinsic motivation. The search for optimal motivation and performance, (pp. 14-54). Thousand Oaks, CA: Academic Press. <http://dx.doi.org/10.1016/B978-012619070-0/50024-6>

Saarnivaara, M. (1996). Tutkija näkyviin [Bring out the researcher]. In M. Saarnivaara (Ed.), Subjektiviteettiä etsimässä. Metodologisia kohtauspaikkoja [Looking for the subjectivity. Methodological encounters] (pp. 105-125). Jyväskylä: University of Jyväskylä.

Salmi, M. (2004). Työn ja perheen yhteensovittamisen kentät [The Fields of Combinations of Work and Family]. In M. Salmi \& J. Lammi-Taskula, (Eds.) Puhelin, mummo vai joustava työaika? Työn ja perheen yhdistämisen arkea [Telephone, granny, or flexible working hours? The everyday life of combining work and family] (pp. 1-9). Helsinki: Statistics Finland.

Tilastokeskus. (2009). Lapsiperheet tyypeittäin äidin iän mukaan 2009 (isä ja lapsia -perheet isän iän mukaan) [Families with children by types in 2009 (daddy and children - families by fathers' age)]. Retrieved from http://stat.fi/til/perh/2009/perh_2009_2010-05-28_kuv_001_fi.html

Uusiautti, S. (2008). "Tänään teen elämäni parhaan työn": työmenestys Vuoden työntekijöiden kertomana [ "Today I'll Work Better than Ever. Employees of the year describe their experiences of success at work]. (Acta Universitatis Lapponiensis 138.) Rovaniemi: University of Lapland.

Uusiautti, S., \& Määttä, K. (2010). What kind of employees become awarded as Employees of the Year in Finland? Enterprise and Work Innovation Studies, 6, 53-73. Retrieved from http://hdl.handle.net/10362/5725

Uusiautti, S., \& Määttä, K. (2010, in press). The successful combination of work and family in Finland: the ability to compromise as a key factor. Journal of Comparative Family Studies.

Uusiautti, S., \& Määttä, K. (2011). Process of becoming a top worker. International Education Studies, 4(4), 69-79. <http://dx.doi.org/10.5539/ies.v4n4p697>

Uusiautti, S. \& Määttä, K. (2011). Top workers virtues and strengths. GJES: Education Sciences and Psychology, 2(19), 46-56. 